\title{
PENGARUH LIKUIDITAS, LEVERAGE DAN PROFITABILITAS TERHADAP STOCK PRICE PADA INDUSTRI MANUFAKTUR
}

\author{
Mohamad Zulman Hakim 1 \\ Arry Eksandy ${ }^{2}$ \\ Program Studi S1 Akuntansi, Fakultas Ekonomi dan Bisnis Universitas \\ Muhammadiyah Tangerang Email: zulman.hakim@umt.ac.id ${ }^{1}$ Email: \\ arry_eksandy@umt.ac.id ${ }^{2}$
}

\begin{abstract}
The purpose of this study is to prove empirically the influence of liquidity, leverage and profitability in manufacturing industries listed on the Indonesia Stock Exchange period 2012-2016. The population in this study uses the manufacturing industry. The sampling technique used purposive sampling technique. Based on the predetermined criteria, the sample of 61 companies is obtained. The type of data used in this study is secondary data using panel data regression analysis method (E-Views 9.0). The results of this study indicate that the Current Ratio (CR) has no effect on Stock Price, Debt to Equity Ratio (DER) has no effect on Stock Price and Return on Equity (ROE) have a positive effect on Stock Price.
\end{abstract}

Keywords: Liquidity, Leverage, Profitability and Stock Price

\begin{abstract}
ABSTRAK
Tujuan dari penelitian ini untuk membuktikan secara empiris pengaruh likuiditas, leverage dan profitabilitas pada industri manufaktur yang terdaftar di Bursa Efek Indonesia periode 2012-2016. Populasi dalam penelitian ini menggunakan industri manufaktur. Teknik pengambilan sampel menggunakan teknik purposive sampling. Berdasarkan kriteria yang telah ditetapkan diperoleh jumlah sampel 61 perusahaan. Jenis data yang digunakan dalam penelitian ini adalah data sekunder dengan menggunakan metode analisis regresi data panel (E-Views 9.0). Hasil penelitian ini menunjukkan bahwa Current Ratio (CR) tidak berpengaruh terhadap Stock Price, Debt to Equity Ratio (DER) tidak berpengaruh terhadap Stock Price dan Return on Equity (ROE) berpengaruh positif terhadap Stock Price.
\end{abstract}

Kata kunci: Likuiditas, Leverage, Profitabilitas dan Stock Price 


\section{Pendahuluan}

\section{Latar Belakang Penelitian}

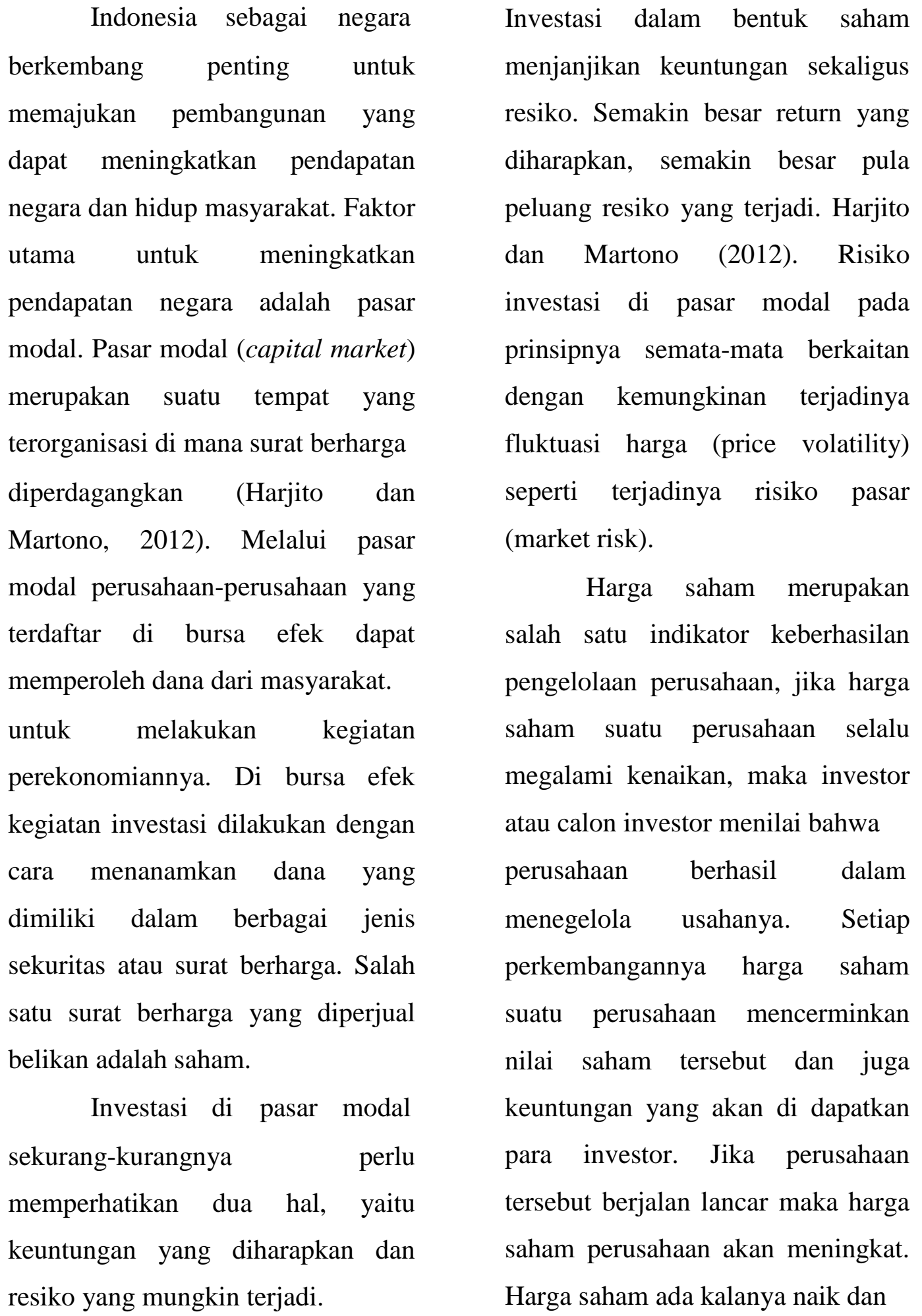


turun tergantung dari kekukatan permintaan dan penawaran (Harjito dan Martono, 2012). Sebelum investor berinvestasi di pasar modal, investor tentunya memerlukan berbagai informasi yang berhubungan dengan dinamika stock price di pasar modal sebagai landasan dalam pengambilan keputusan. Para investor tentunya membutuhkan informasi terpercaya dan relevan yang diperoleh dari

laporan keuangan perusahaan. Fenomena tersebut dapat dilihat bahwa harga saham setiap perusahaan tidak selamanya mengalami peningkatan dari tahun ke tahunnya. Fluktuasi tersebut disebabkan oleh tinggi atau rendahnya kinerja suatu perusahaan. Investor yang menginvestasikan dananya ke saham perusahaan pada dasarnya menginginkan keuntungan baik berupa deviden atau capital gain. Di mata Investor nilai perusahaan yang baik tercermin dari harga saham yang tinggi dan cenderung membaik dari tahun ke tahun. Sondakh dan Mangantar (2015). Untuk menaikkan nilai perusahaan dan memaksimalkan keuntungan salah satunya dengan lebih meningkatkan kinerja keuangan perusahaan. Aspek-aspek yang dinilai berdasarkan rasio-rasio yang dicapai oleh perusahaan antara lain Rasio Likuiditas, Leverage dan Profitabilitas.

Current Ratio $(C R)$ merupakan kemampuan perusahaan dalam membayar kewajiban jangka pendek dengan aktiva lancar yang di miliki. Semakin tinggi Current Ratio berarti semakin besar kemampuan perusahaan untuk memenuhi kewajiban financial jangka pendek (Maskun, 2012). Penelitian yang dilakukan oleh sondakh dan mangantar (2015) menyatakan bahwa Current Ratio $(C R)$ berpengaruh positif terhadap harga saham. Sedangkan Penelitian yang di lakukan Maskun (2012) menyatakan bahwa Current Ratio (CR) tidak berpengaruh terhadap harga saham.

Debt to Equity Ratio (DER) merupakan rasio yang digunakan untuk mengukur tingkat hutang terhadap total equity yang dimiliki perusahaan. Semakin besar DER menunjukkan semakin besar biaya 
hutang yang harus di bayar perusahaan. Dewi dan suaryana

(2013) dalam penelitiannya menyatakan bahwa Debt to Equity Ratio (DER) berpengaruh negatif terhadap harga saham. Hal tersebut berbeda dengan penelitian Safitri (2013) yang menyatakan bahwa Debt to Equity Ratio (DER) tidak berpengaruh terhadap harga saham.

Return on Equity (ROE)

digunakan untuk mengukur besarnya pengembalian terhadap harga saham.

Semakin besar Return on Equity (ROE) maka semakin besar harga saham yang berarti perusahaan mampu memberikan imbal hasil kepada pemegang saham. Dalam penelitian sondakh dan mangantar (2015) menyatakan bahwa Return on Equity (ROE) berpengaruh positif terhadap harga saham. Penelitian tersebut berbeda dengan penelitian Maskun (2012) bahwa Return on Equity (ROE) tidak berpengaruh terhadap harga saham.

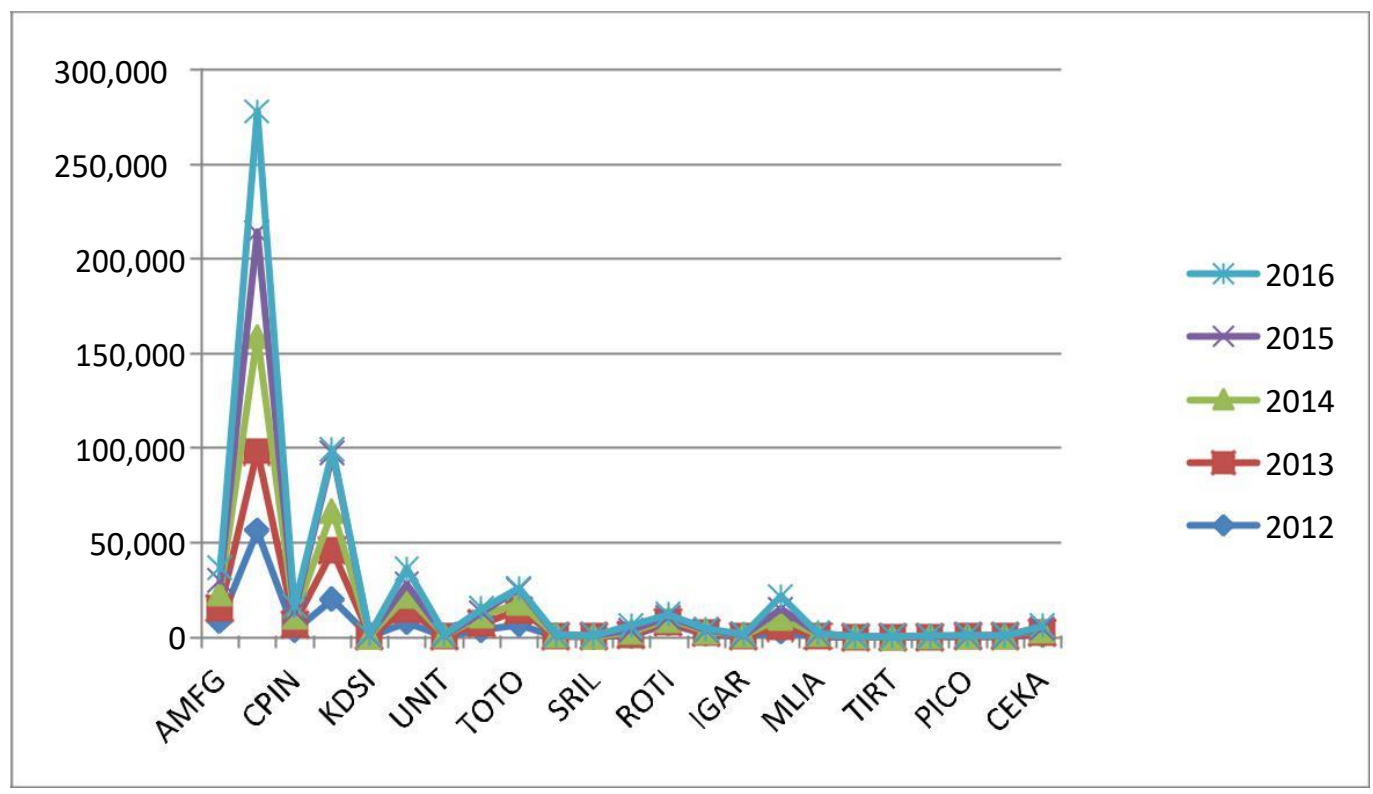

Grafik 1.

Pergerakan Stock Price Industri Manufaktur Periode 2012-2016 
2. Perumusan Masalah Penelitian

1). Apakah Current Ratio (CR) berpengaruh terhadap Stock Price?

2). Apakah Debt to Equity Ratio (DER) berpengaruh terhadap Stock Price?

3). Apakah Return on Equity (ROE) berpengaruh terhadap Stock Price?

\section{Tujuan Penelitian}

1). Untuk membuktikan secara empiris pengaruh Current Ratio $(C R)$ terhadap Stock Price?

2). Untuk membuktikan secara empiris pengaruh Debt to Equity Ratio (DER) terhadap Stock Price?

3). Untuk membuktikan secara empiris pengaruh Return on Equity (ROE) terhadap Stock Price?

\section{Manfaat Penelitian}

1). Manfaat Teoritis

Hasil penelitian ini diharapkan dapat memberikan manfaat berupa tambahan ilmu pengetahuan terutama mengenai harga saham pada perusahaan manufaktur. Serta dapat memperkaya konsep atau teori yang menyokong perkembangan ilmu pengetahuan dan diharapkan dapat dijadikan sebagai bahan referensi untuk rancangan penelitian berikutnya.

2). Manfaat Praktis dan Penentu Kebijakan

a. Bagi perusahaan atau emiten Hasil penelitian ini dapat digunakan sebagai salah satu sumber atau bahan masukan tentang faktor yang mempengaruhi harga saham khususnya Current Ratio (CR), Return on Equity (ROE), Debt to Equity Ratio (DER) sehingga perusahaan dapat meningkatkan nilai harga saham.

b. Bagi investor dan calon investor 


Hasil penelitian ini
diharapkan dapat memberikan
informasi atau menjadi acuan
bagi investor maupun calon

investor yang akan

menanamkan modal sebagai

bahan pertimbangan dalam

mengambil keputusan

berinvestasi.

Tinjauan Pustaka dan

\section{Perumusan Hipotesis}

\section{Signalling Theory}

Signalling

theory

menjelaskan tentang bagaimana

para investor memiliki informasi

yang sama tentang prospek

perusahaan sebagai manajer

perusahaan. Namun dalam

kenyataannya manajer sering memiliki informasi lebih baik dari investor luar. Hal ini disebut informasi asimetris, dan ini memiliki dampak paling penting pada struktur modal yang optimal. Hal ini akan terlihat jika manajemen tidak secara penuh menyampaikan semua informasi yang diperoleh tentang semua hal yang dapat mempengaruhi perusahaan, maka umumnya pasar akan merespon informasi tersebut sebagai suatu sinyal terhadap suatu kejadian yang akan mempengaruhi nilai perusahaan yang tercermin melalui harga saham Sri Sulistyanto (2008).

Harjono (2010) dalam Eva Liana (2015) menyatakan bahwa "teori sinyal menyatakan bahwa perusahaan yang berkualitas baik dengan sengaja akan memberikan sinyal pada pasar, dengan demikian pasar diharap dapat membedakan perusahaan yang berkualitas baik atau buruk.

\section{Harga Saham (Stock Price)}

Saham adalah surat berharga sebagai bukti penyertaan atau pemilik individu maupun institusi yang dikeluarkan oleh sebuah perusahaan yang berbentuk Perseroan Terbatas (PT). Saham yang dimaksud disini adalah saham yang berasal dari perusahaan lain, yang dibeli oleh pihak manajemen perusahaan dan sewaktu-waktu bisa di jual kembali jika membutuhkan 
dana dan hasil keuntungan penjualan akan masuk ke kas perusahaan (Fahmi, 2013).

Harga saham merupakan salah satu indikator keberhasilan pengelolaan perusahaan, jika harga Kepercayaan investor atau calon investor sangat bermanfaat bagi emiten, karena semakin banyak orang yang percaya terhadap emiten maka keinginan untuk berinvestasi pada emiten semakin kuat. Semakin banyak permintaan terhadap saham suatu emiten maka dapat menaikkan harga saham tersebut. Jika harga

saham yang tinggi dapat dipertahankan maka kepercayaan investor atau calon investor terhadap emiten juga semakin tinggi dan hal ini dapat menaikkan nilai emiten. Sebaliknya, jika harga saham mengalami penurunan terus-menerus berarti dapat menurunkan nilai emiten dimata investor atau calon investor.

\section{Menurut Sawidji (1996)} dalam Onibala , Tommy dan Paulina (2014) harga saham dapat dibedakan menjadi 3 (tiga):

a. Harga Nominal saham suatu perusahaan selalu mengalami kenaikan, maka investor atau calon investor menilai bahwa peruasahaan berhasil dalam mengelola usahanya.

Harga yang tercantum dalam sertifikat saham yang ditetapkan oleh emiten untuk menilai setiap lembar saham yang dikeluarkan. Besarnya harga nominal memberikan arti penting saham karena deviden minimal biasanya ditetapkan berdasarkan nilai nominal.

b. Harga Perdana

Harga ini merupakan pada waktu harga saham tersebut dicatat di bursa efek. Harga saham pada pasar perdan biasanya ditetapkan oleh penjamin emisi (underwriter) dan emiten. Dengan demikian akan diketahui berapa harga saham emiten itu akan dijual kepada masyarakat biasanya untuk menentukan harga perdana.

c. Harga Pasar

Jika harga perdana merapakan harga jual dari perjanjian emisi kepada investor, maka harga pasar adalah harga jual dari investor yang satu dengan investor yang 
lain. Harga ini terjadi setelah saham tersebut dicatatkan di bursa. Transaksi disini tidak lagi melibatkan emiten dari penjamin emisi harga ini yang disebut sebagai harga di pasar sekunder

\section{Perumusan Hipotesis}

\section{a. Current Ratio (CR)}

Semakin tinggiCurrent Ratio $(C R)$ berarti semakin besar kemampuan perusahaan untuk memenuhi kewajiban financial jangka pendek (Kasmir, 2015). Dengan demikian semakin tinggi kemampuan perusahaan untuk memenuhi kewajiban financial jangka pendek, semakin tinggi, pula harga saham. Sebaliknya semakin rendah kemampuan

\section{b. Debt to Equity Ratio (DER)}

Investortidakhanya

berorientasi terhadap laba, namun memperhitungkan tingkat risiko yang dimiliki oleh perusahaan.

Tingkat risiko perusahaan tercermin dari rasio $D E R$ yang menunjukkan seberapa besar modal sendiri yang dimiliki oleh perusahaan dalam memenuhi kewajiban-kewajiban perusahaan. Setiap investor tentu saja dan harga inilah yang benar-benar mewakili harga perusahaan penerbitnya, karena pada transaksi di pasar sekunder, kecil sekali terjadi negosiasi harga investor dengan perusahaan penerbit.

perusahaan untuk memenuhi kewajiban financial jangka pendek mengakibatkan harga saham turun. Hal ini sejalan dengan penelitian Pratama dan Erawati (2014) yang menyatakan bahwa Current Ratio (CR) berpengaruh positif terhadap Harga Saham

\section{H1: $C R$ Berpengaruh positif} terhadap harga saham.

menghindari berinvestasi pada perusahaan yang memiliki angka DER tinggi karena mencerminkan tingkat risiko yang tinggi pula. Hal ini akan mempengaruhi penilaian investor sehingga harga saham mengalami penurunan. Semakin besar $D E R$ menunjukkan semakin besar biaya hutang yang harus dibayar perusahaan. Hal ini menyebabkan hak para pemegang saham 
berkurang dan akan berpengaruh pada minat investor Hasil penelitian Dewi dan Suaryana (2013) yang menyatakan bahwa

\section{c. Return on Equity (ROE)}

Para investor akan lebih mencari perusahaan dengan tingkat profitabilitas yang tinggi, karena dianggap mampu memberikan return yang tinggi, bagi para kreditor laba yang dihasilkan perusahaan akan digunakan untuk membayar tinggkat bunga dan pokok pinjaman, sehingga kreditor mengharapkan peningkatan laba perusahaan. Hal ini sesuai

\section{Metode Penelitian}

\section{Populasi dan Sampel}

Populasi dalam penelitian ini adalah perusahaan yang terdaftar di Bursa Efek Indonesia (BEI) dan masuk dalam perusahaan manufaktur periode 2012-2016. Teknik pengambilan sampel yang digunakan adalah metode purposive sampling.

Perusahaan manufaktur yang telah memenuhi kriteria sebagai
DER berpengaruh negatif terhadap harga saham.

\section{H2: DER berpengaruh negatif} terhadap harga saham.

dengan hasil penelitian yang menunjukan bahwa Return on Equity (ROE) berpengaruh positif terhadap nilai perusahaan yang berarti peningkatan $R O E$ akan mempengaruhi peningkatan harga saham perusahaan secara signifikan. Hal ini didukung oleh penelitian Hartini (2015) yang menyatakan bahwa Return on Equity (ROE) berpengaruh positif terhadap harga saham.

\section{H3 : ROE Berpengaruh positif} terhadap harga saham

sampel penelitian sebanyak 61 perusahaan selama 5 tahun penelitian, sehingga jumlah data yang digunakan dalam penelitian ini sebanyak 305 data observasi.

\section{Definisi dan Pengukuran Variabel}

\section{a. Variabel Independen}

Dalam penelitian ini terdapat 3 (tiga) variabel independen, yaitu: 
1) Current Ratio ( $\left.X_{1}\right)$

Current Ratio (CR) merupakan perbandingan antara aktiva lancar (current asset) dengan hutang lancar (current liabilities). Rumus untuk mencari rasio lancar atau current ratio dapat digunakan fumus, sebagai berikut :

(Sumber: Fahmi, 2013)

\section{2) Debt to Equity Ratio $\left(\mathrm{X}_{2}\right)$}

Debt to Equity Ratio (DER) merupakan rasio yang digunakan untuk mengukur tingkat leverage terhadap total shareholders equity yang dimiliki perusahaan (Safitri, 2013). Rasio ini menunjukan presentase penyediaan dana oleh pemegang saham terhadap pemberi pinjaman (Sumarsan, 2013). Rumus untuk mencari Debt to

Equity Ratio (DER) dapat
digunakan perbandingan antara
total hutang dengan ekuitas,
sebagai berikut:

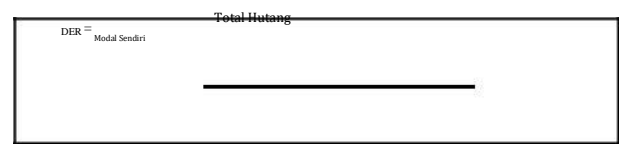

(Sumber: Harjito dan

Martono, 2012)

\section{3) Return on Equity (X3)}

Return on Equity (ROE) adalah indikator untuk mengukur kemampuan modal sendiri untuk menghasilkan keuntungan Ali Maskun (2012). Rasio ini mengkaji sejauh mana suatu perusahaan mempergunakan sumber daya yang dimiliki untuk mampu memberikan laba atas ekuitas. Rumus untuk mencari $R O E$, Sebagai berikut:

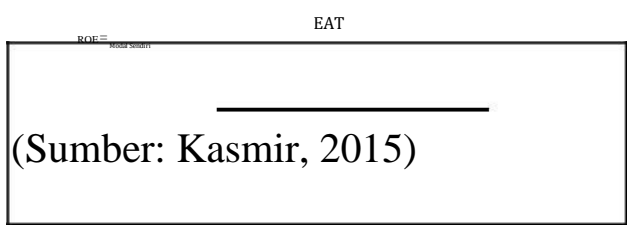

\section{b. Variabel Dependen}

Harga saham merupakan salah satu indikator keberhasilan pengelolaan perusahaan, jika harga saham suatu perusahaan selalu mengalami kenaikan, maka investor atau calon investor menilai bahwa peruasahaan berhasil dalam mengelola usahanya. Kepercayaan investor atau calon investor sangat bermanfaat bagi emiten, karena semakin banyak orang yang percaya 
terhadap emiten maka keinginan untuk berinvestasi pada emiten semakin kuat. Semakin banyak permintaan terhadap saham suatu emiten maka dapat menaikkan harga saham tersebut. Jika harga saham yang tinggi dapat dipertahankan maka kepercayaan investor atau calon investor terhadap emiten juga semakin tinggi dan hal ini dapat menaikkan nilai emiten. Sebaliknya, jika harga saham mengalami penurunan terus-menerus berarti dapat menurunkan nilai emiten dimata investor atau calon investor.

Harga Saham pada penelitian ini merupakan harga penutupan yang terjadi setiap akhir tahun selama periode pengamatan.

\section{Hasil dan Pembahasan}

\section{Analisis Statistik Deskriptif}

\begin{tabular}{|l|c|c|c|c|}
\hline & PRICE & CR & ROE & DER \\
\hline Mean & 7.311934 & 2.660033 & 0.166852 & 0.876656 \\
\hline Maximum & 12.87000 & 15.16000 & 1.360000 & 7.400000 \\
\hline Minimum & 3.910000 & 0.400000 & 0.000000 & 0.080000 \\
\hline Std. Dev. & 1.872431 & 2.174681 & 0.170454 & 0.871191 \\
\hline
\end{tabular}

Berdasarkan data di atas, maka diperoleh hasil, sebagai berikut: Harga saham di ukur dengan Ln Closing Price memiliki nilai

\section{Metode Analisa Data}

Dalam penelitian ini, metode analisis data yang digunakan adalah analisis regresi data panel dengan bantuan software pengolah data statistik, yaitu Eviews 9.0. Model penelitian regresi data panel, sebagai berikut:

Keterangan:

= Harga Saham (Stock Price)

$=$ Konstanta

$=$ Current Ratio $(C R)$

$=$ Debt to Equity Ratio (DER)

= Return on Equity (ROE)

$=$ Komponen error

minimum 3.91 pada PT. Indo Acitama, Tbk dan nilai maksimum 12.87 pada PT. Delta Djakarta, Tbk. dengan nilai rata-rata 7.31 dan standar deviasi 1.87 .

Current Ratio memiliki nilai minimum 0.40 pada PT. Nusantara Inti Corpora, Tbk. dan nilai maksimum 15.16 pada PT. Duta Pertiwi Nusantara, Tbk dengan nilai rata-rata 2.66 dan standard deviasi 2.17 . 
Return on Equity memiliki nilai minimum 0.000000001 pada PT. Star Petrochem, Tbk dan nilai maksimum 1.36 pada PT. Unilever Indonesia, Tbk dengan rata-rata 0.16 dan standar deviasi 0.17 .

Debt to Equity Ratio memiliki nilai minimum 0.08 pada PT. Intan Wijaya International, Tbk. dan nilai maksimum 7.40 pada PT. Jemblo Cable Company, Tbk. dengan ratarata 0.87 dan standar deviasi 0.87 .

\section{Pemilihan Model Regresi Data}

\section{Panel}

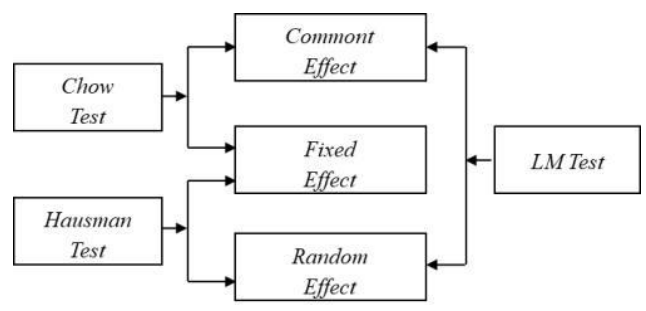

Skema Pemilihan Model Regresi Data Panel

\section{a. Uji Chow}

Hipotesis dalam Chow Test adalah sebagai berikut:

$\mathrm{H}_{0}$ : Model mengikuti common effect $\mathrm{H}_{1}$ : Model mengikuti fixed effect

\begin{tabular}{|c|c|}
\hline \multicolumn{2}{|c|}{$\begin{array}{l}\text { Redundant Fixed Effects Tests } \\
\text { Equation: Untitled } \\
\text { Test cross-section fixed effects }\end{array}$} \\
\hline Effects Test & Statistic \\
\hline on $\mathrm{F}$ & $26.766462(60,24$ \\
\hline Cross-section Chi-square & 621.136896 \\
\hline
\end{tabular}

Berdasarkan tabel di atas, terlihat bahwa $p$-valuecross-section F dan p-value cross-sectionchisquare lebih kecil dari $\alpha(0,05)$, maka $\mathrm{H}_{0}$ ditolak, artinya model fixed effect lebih layak digunakan dalam mengestimasi regresi data panel dibandingkan model common effect.

\section{b. Uji hausman}

Hipotesis dalam Hausman test adalah sebagai berikut:

$\mathrm{H}_{0}$ : Model mengikuti random effect

$\mathrm{H}_{1}$ : Model mengikuti fixed effect

\begin{tabular}{|c|c|}
\hline \multicolumn{2}{|c|}{$\begin{array}{l}\text { Correlated Random Effects - Hausman Test } \\
\text { Equation: Untitled } \\
\text { Test cross-section random effects }\end{array}$} \\
\hline Test Summary & $\begin{array}{l}\text { Chi-Sq. } \\
\text { Statistic Chi-Sq. d.f. Prob. }\end{array}$ \\
\hline Cross-section random & 5.681071 \\
\hline
\end{tabular}

Berdasarkan tabel di atas, terlihat bahwa $p$-value cross-section random lebih besar dari $\alpha(0,05)$, maka $\mathrm{H}_{0}$ diterima, artinya model random effect lebih layak digunakan dalam mengestimasi regresi data 
panel dibandingkan model fixed

effect.

\section{c. Uji Lagrange Multiplier Test}

HipotesisdalamLagrange

Multiplier Test, sebagai berikut:

$\mathrm{H}_{0}$ : Model mengikuti common effect

$\mathrm{H}_{1}$ : Model mengikuti random effect

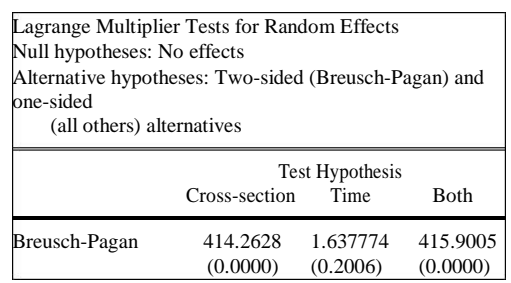

Berdasarkan tabel di atas, terlihat bahwa $p$-value cross section Breusch-Pagan lebih kecil dari $\alpha$ $(0,05)$, maka $\mathrm{H}_{0}$ ditolak, artinya model random effect lebih layak digunakan dalam mengestimasi regresi data panel dibandingkan model common effect.

\section{d. Kesimpulan Model}

Berdasarkan

pengujian

terhadap ketiga model regresi data panel, dapat disimpulkan bahwa model random effect dalam regresi data panel digunakan lebih lanjut dalam mengestimasi pengaruh Current Ratio (CR), Debt To Equity Ratio (DER) dan Return On Equity $(R O E)$ terhadap Harga Saham pada
Industri manufaktur yang terdaftar di Bursa Efek Indonesia periode 20122016.

\section{Uji Hipotesis}

a. Uji F

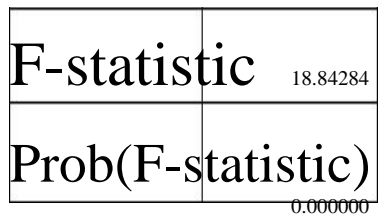

Berdasarkan perhitungan di atas bahwa nilai F- Statistic sebesar 18.84284. sementara $F$ tabel dengan tingkat $\alpha$ 5\% df1 (k-1) dimana (k adalah jumlah variabel) dan df2 (n-k) dimana (n adalah jumlah data). Maka df1 (4-1) = 3 dan df2 (305-4) = 301 di dapat nilai $\mathrm{F}$ tabel sebesar 2.63460. dengan demikian F statistic sebesar $18.84284>$ dari $\mathrm{F}$ tabel sebesar 2.63460 dan prob F-Statistic $0.000000<0.05$, maka dapat disimpulkan seluruh variabel independen yaitu Current Ratio (CR) , Return on Equity (ROE) dan Debt to Equity Ratio (DER) secara bersama sama memiliki pengaruh signifikan terhadap variabel dependen yaitu harga saham.

b. $\mathbf{U j i} \mathbf{R}^{2}$ 


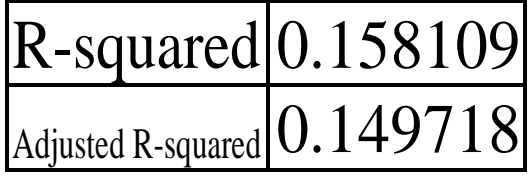

Berdasarkan perhitungan di

atas menunjukan bahwa nilai

koefisien determinasi $\left(\mathrm{R}^{2}\right)$ sebesar

0.158109, artinya bahwa variasi

perubahan naik turunya harga saham dapat dijelaskan oleh Current Ratio ,

Return on Equity dan Debt to Equity Ratio sebesar $15.81 \%$ sementara sisanya yaitu sebesar $84.19 \%$ dijelaskan oleh variabel-variabel diluar penelitian ini.Untuk koefisien determinasi yang disesuaikan (adjusted $R^{2}$ ) menunjukkan nilai sebesar 0.149718 yang berarti bahwa setelah mempertimbangkan derajat kebebasan model yang digunakan, seluruh variabel independen yang digunakan dalam penelitian ini masih dapat menjelaskan harga saham sebesar $14.97 \%$.

\section{c. Uji t}

\begin{tabular}{|ccc|}
\hline Variable & t-Statistic & Prob. \\
\hline \hline C & 25.37439 & 0.0000 \\
CR & 0.785200 & 0.4330 \\
ROE & 7.536802 & 0.0000 \\
DER & -0.693529 & 0.4885 \\
\hline
\end{tabular}

\section{1) Pengaruh Current Ratio (CR)}

\section{Terhadap Harga Saham.}

Berdasarkan perhitungan tabel di atas nilai t-statistic $C R$ sebesar 0.785200 sementara $t$ table dengan tingkat $\alpha 5 \%$, df (n-k-1) $=301 \mathrm{di}$ dapat nilai $\mathrm{t}$ table sebesar 1.64993. Dengan demikian $t$ statistic $C R$ sebesar $(0.785200)<\mathrm{t}$ table (1.64993), dan nilai prob sebesar $0.4330>0.05$, maka dapat disimpulkan bahwa $\mathrm{H} 0$ di terima dan H1 ditolak, artinya bahwa variabel Current Ratio dalam penelitian ini tidak berpengaruh terhadap harga saham.

\section{2) Pengaruh Debt to Equity Ratio} (DER) Terhadap Harga Saham.

Berdasarkan tabel di atas nilai $t$ statistic DER sebesar -0.693529, sementara $\mathrm{t}$ table dengan tingkat $\alpha$ $5 \%$, df $(n-k-1)=301$ di dapat nilai $t$ table sebesar 1.64993. dengan demikian $t$ statistic DER sebesar $(0.693529)<\mathrm{t}$ table $(1.64993)$ dan nilai prob sebesar $0.4885>0.05$ maka dapat disimpulkan bahwa $\mathrm{H} 0$ diterima dan $\mathrm{H} 2$ di tolak, artinya bahwa variabel Debt to Equity 
Ratio tidak berpengaruh terhadap harga saham.

3) Pengaruh Return on Equity (ROE) Terhadap Harga Saham.

Berdasarkan tabel di atas nilai t statistic ROE sebesar 7.536802, sementara $\mathrm{t}$ table $\alpha 5 \%$, df $(\mathrm{n}-\mathrm{k}-1)=$ 301 di dapat nilai $t$ table sebesar 1.64993. dengan demikian $t$ statistic ROE sebesar (7.536802) > $\mathrm{t}$ table (1.64993) dan nilai prob sebesar $0.0000<0.05$ maka dapat di simpulkan bahwa $\mathrm{H} 0$ ditolak dan H3 di terima, artinya bahwa

variabel Return on Equity berpengaruh dan positif terhadap harga saham.

\section{Kesimpulan}

Berdasarkan hasil pengujian yang telah dilakukan, dapat disimpulkan beberapa hal sebagai berikut:

1). Current Ratio (CR) tidak terbukti secara empiris berpengaruh positif terhadap harga saham pada Industri manufaktur di Bursa Efek Indonesia periode 2012-2016. Hal ini dibuktikan dengan hasil $\mathrm{t}$ statistic $C R$ sebesar $(0.785200)<\mathrm{t}$ table
(1.64993), dan nilai prob sebesar $0.4330>0.05$. Dengan demikian, maka Current Ratio (CR) tidak berpengaruh terhadap harga saham. 2). Debt to Equity Ratio (DER) tidak terbukti secara empiris berpengaruh negatif terhadap harga saham pada Industri manufaktur di Bursa Efek Indonesia periode 2012-2016. Hal ini dibuktikan dengan hasil t statistic DER sebesar $(0.693529)<\mathrm{t}$ table (1.64993) dan nilai prob sebesar $0.4885>0.05$. Dengan demikian, maka Debt to Equity Ratio (DER) tidak berpengaruh terhadap harga saham.

3). Return on Equity (ROE) secara empiris berpengaruh positif terhadap harga saham pada Industri manufaktur di Bursa Efek Indonesia periode 2012-2016 Hal ini dibuktikan dengan hasil diperoleh tstatistic ROE sebesar (7.536802) > t table (1.64993) dan nilai prob sebesar $0.0000<0.05$. Semakin tinggi Return on Equity berarti semakin efisien penggunaan modal sendiri yang di lakukan oleh pihak manajemen perusahaan untuk menguntungkan bagi pihak pemegang saham. Return on Equity 
(ROE) merupakan rasio penting bagi para pemilik dan pemegang saham karena rasio tersebut menunjukkan kemampuan perusahaan dalam mengelola modal untuk mendapatkan laba bersih setelah pajak. Perusahaan yang memiliki Return on Equity (ROE) yang rendah atau bahkan negatif akan terklasifikasikan sebagai perusahaan yang memiliki kinerja yang kurang baik atau bad performance perusahaan.

\section{Keterbatasan penelitian}

Keterbatasan dari penelitian ini, yaitu variabel -

variabel independen yang digunakan dalam penelitian ini hanya menggunakan faktor internal perusahaan (Current Ratio, Debt to Equity Ratio, Return on Equity) masih belum maksimal menjelaskan variasi variabel dependen, yaitu harga saham. Hal ini juga ditunjukkan dengan nilai Adjusted $R$ square yang relatif kecil sebesar $14,97 \%$.

\section{Rekomendasi}

$$
\text { Rekomendasi yang }
$$

diajukan untuk penelitian selanjutnya, yaitu menambahkan faktor eksternal perusahaan, seperti inflasi, tingkat suku bunga dan kurs

valuta asing sehingga diharapkan dapat lebih maksimal menjelaskan variasi

variabel dependen, yaitu harga saham.

\section{Referensi}

Dewi, Putu Dina Aristya dan Suaryana, I.G.N.A.. Pengaruh Eps, Der dan Pbv Terhadap Harga Saham, E-Jurnal Akuntansi Universitas Udayana 4.1 (2013): 215-229. 
Eksandy, Arry dan Haryanto, Fredy. 2017. Modul Metedologi Penelitian Akuntansi dan Keuangan Regresi data panel dan Logistik data panel.

Fahmi, Irham. 2013. Analisis Laporan Keuanagan. Bandung: Alfabeta.

Harjito, Agus dan Martono. 2012. Manajemen Keuangan, Edisi Kedua, Cetakan Kedua. Yogyakarta: Ekonisia.

Hartini, Revida Sihite Ronauli. Pengaruh capital structure, financial leverage dan profitability Terhadap Harga Saham Pada Perusahaan Manufaktur Yang Terdaftar Di Bursa Efek Indonesia . Jurnal
Manajemen Keuangan

Trisakti (e-Journal)

Volume. 1 Nomor. 1

September 2015.

Ikatan Akuntansi Indonesia. 2015,

Standar

Akuntansi

Keuanagan. Jakarta:

Salemba Empat.

Kasmir. 2015. Analisis Laporan Keuangan. Cetakan Ke-8, Jakarta: PT RajaGrafindo Persada.

Liana, Eva. Pengaruh Economi Value Added (EVA), Market Value Added (MVA) dan Laverage Terhadap Harga Saham. Skripsi Fakultas Ekonomi dan Bisnis, 2015.

Maskun,Ali. Pengaruh Current Rasio, Return on Equity, Return on Asset, Earning Per Share Terhadap Harga Saham pada Perusahaan Food and Beverages yang Go Public di BEJ, Jurnal

Mitra Ekonomi dan Manajemen Bisnis, Vol.3, No. 2, Oktober 2012, 211222. 
Nurfadillah, Mursidah. Analisis Pengaruh Earning Pershare , Debt to Equity Ratio, dan Return on Equity.terhadap harga saham PT unilever Indonesia tbk. Jurnal vol.12 no.1 april 2011.

Onibala,Indra Ricky. Tomy, Parengkuan dan Rate, Paulina Van. Analisis Rasio Probitabilitas dan Risiko Keuangan Terhadap Harga Saham XL Axiata Tbk Yang Terdaftar Di BEI Periode 2007-2012, Jurnal EMBA Vol.2 No.1 Maret 2014, Hal. 374-384.

Pratama, Aditya dan Erawati Teguh. Pengaruh Current Ratio, Debt to Equity Ratio , Return on Equity Net Profit Margin dan Earning PerShare Terhadap Harga Saham. Jurnal Akuntansi. Vol.2 No.1 Juni 2014.

Sugiyono. 2014. Metode Penelitian

Kuantitif Kualitatif dan

$R \& D$. Bandung: Alfabeta. -. 2015. Statistika Untuk

Penelitian. Bandung : Alfabeta.
Safitri, Abied Luthfi. Pengaruh Earning Per Share, Price Earning Ratio, Return On Asset, Debt to Equity Ratio dan Market Value Added Terhdap Harga Saham Dalam Kelompok Jakarta

Islamic Index, Jurnal Universitas Negeri Semarang. 2 (2) (2013).

Sulistyanto, Sri. 2008. Manajemen Laba (Teori dan Model Empiris) Jakarta: Grasindo. Susilowati. Yeye. Reaksi Signal Rasio Profitabilitas dan Rasio Solvabilitas Terhadap Return Saham Perusahaa. Jurnal Dinamika Keuangan dan Perbankan, No. 1, Mei, Vol.3, 2011)

Sondakh, Tommy dan Mangantar. Current Ratio, Debt to Equity Ratio, Return on Asset, Return on Equity Pengaruhnya Terhadap Harga Saham Pada Indexs LQ 45 di BEI Periode 2010-2014, Jurnal EMBA Vol.3 No.2 Juni 2015, Hal. 749-756. 
Sumarsan, Thomas, 2013. Sistem

Pengendalian Manajemen,

Jakarta: Indeks.

Sriyana, Jaka. 2014. Metode Regresi

Data Panel, Edisi Pertama,

Cetakan Pertama,

Yogyakarta: Ekonisia.

Winarno, Wing Wahyu, 2015.

Analisis Ekonometrika dan

Statistic dengan Eviews,

Edisi Keempat, Cetakan

Pertama, Yogyakarta: UPP

STIM YKPN.

www.idx.co.id

www.sahamok.com 